\title{
Influence of TQM (Total Quality Management) on Organisation's Service Performance in Public Higher Learning Institutions
}

\author{
Zainuddin Bin Zakaria \\ Faculty of Business Management \\ UiTM Terengganu, Dungun Campus \\ Dungun, Malaysia \\ hzainuddin67@gmail.com \\ Zuriyati Ahmad \\ Faculty of Business Management \\ UiTM Terengganu, Dungun Campus \\ Dungun, Malaysia
}

Mazlin Athirah Mazlan

Faculty of Business Management

UiTM Terengganu, Dungun Campus

Dungun, Malaysia

\author{
Md Noh Ab Majid \\ Faculty of Business Management \\ UiTM Terengganu, Dungun Campus \\ Dungun, Malaysia
}

\author{
Norchahaya Johar \\ Faculty of Business Management \\ UiTM Terengganu, Dungun Campus \\ Dungun, Malaysia
}

\begin{abstract}
This paper focus on examining the relationship between TQM (Total Quality Management) elements and service performance to students in public higher learning institutions. The purpose of this study is to identify the relationship between the elements of TQM in achieving excellent service performance to students in public higher learning and the most dominant element. The public institutions of higher learning involved in this study are UiTM Kota Bharu, Universiti Malaysia Kelantan, and University Malaya. In this study, the service performance indicators involved are academic performance, facilities, technology, faculty, transportation, and accommodation whereas the elements of TQM are management support, continuous improvement, training and education, and customer focus. The data have been analyzed using the descriptive analysis, correlation analysis, and multiple regression analysis. The findings of this research indicated that customer focus is the most important element of TQM in achieving excellent service performance for students at public higher learning institutions. The findings also indicated that the TQM element 'management support' have a weak relationship with the service performance to students. This may be due to all three institutions involved in this study are branch campuses.
\end{abstract}

Keywords-TQM; Service Performance; Higher Learning Institutions; Students

\section{INTRODUCTION}

Lately, consumers are showing a great deal of concern about the quality of products and services and have started to value the products that they buy or the services that they experience. Quality means the ability of a product or service to meet the customer needs. Quality has been the focus of various sectors through approaches of inspections, quality control, quality assurance and TQM [1][2]. Ahmad and Elhunim, 2014) which engaged all business components in the application of quality management aspects [3][4].

It is essential for organizations to provide high-quality products or services to their customers not only to gain the competitive advantage against their competitors but also to create a strong customer base in the market and to retain loyal customers. A strong customer base will help them to stay in the market for a long time. In addition, organizations can also charge higher prices because most customers are willing to pay for superior products and services.

Poor quality products and services, on the other hand, will increase the cost of quality (COQ). The cost of quality includes prevention, appraisal, internal failure and external failure costs. For example, an organization needs to scrap defective products and incur additional production costs to replace them. Therefore, organizations should have an effective quality control system to reduce cost and increase profit since a good financial management will increase the business performance.

The purpose of this research is to study the relationship between TQM (Total Quality Management) elements and service performance to students in public higher learning institutions in Kota Bharu, Kelantan. The purpose of the research is to identify the elements of TQM that influence the service performance in public higher learning institutions. TQM is an important concept that helps organizations in 
improving the quality of their service performance in order to fulfill customer needs and wants.

Institutions with good service performance will be able to produce superior products. The product of public institutions of higher learning are students who will be employed after graduation. Top-quality products of the institution may eventually become a part of the top management in the organization that they are employed in if they are able to effectively apply the knowledge and skills gained at the university in the workplace. If the institutions improve their service performance, they will be able to produce first-class graduates that will be of value to organizations as well as the society.

\section{A. Problem Statement}

There are three main problems faced by the students at the three public institutions of higher learning which include inadequate facilities, limited access and utilization of public transport. These problems will influence the service performance provided by the institutions to their students. Failure to overcome these problems will affect the students' satisfaction.

\section{1) Inadequate Physical Facilities}

Facilities have a great impact on the academic performances of students where inadequate facilities may translate to poor performance. Students have increasing expectations and demands of their educational experience. They expect lucrative return on investment either in academic quality, administration and facilities offered to them. For instance, students expect their learning process to be more interesting, more flexible delivery option with unique teaching materials [5]. Inadequate facilities such as lack of overhead projector as a teaching tool may hinder the transfer of knowledge from the instructor to the students. This could affect their academic performances. Therefore, the institutions need to ensure that they provide sufficient facilities such as classrooms equipped with the necessary teaching tools in order to enhance students' learning.

\section{2) Limited Internet Access}

Students, faculty, or staff may experience wireless connection issues on campus. These issues include unable to connect to $\mathrm{Wi}-\mathrm{Fi}$, limited or no connectivity, intermittent connectivity, slow performance, or weak signals. Currently, most universities encourage the use of blended learning, a teaching method that combines face to face traditional method of teaching and online learning. However, effective blended learning requires good internet connection. Furthermore, the internet provides students with unlimited information for them to access when they need to complete assignments. Limited internet access will further complicate the students' learning process.

\section{3) Lack of Public Transportation}

Although there is public transportation such as buses in the vicinity of the institutions, only a small number of students are willing to use the transportation service because the bus schedules are not flexible and sometimes does not match with the students' class timetable. Therefore, some students resort to bringing their transportation such as motorcycles or cars to the campus. Due to this situation, the institutions have to provide more parking lots for the students which may be difficult due to lack of space. Therefore, the institutions must find a suitable method to attract the students to use public transportation.

\section{B. Scope of Study and Research Objectives}

This study focus on the relationship between TQM (Total Quality Management) elements and service performance to students at the public higher learning institutions. The variable that was analyzed in this research is service performance to students as the dependent variable while management support, continuous improvement, training and education, and customer focus as the independent variables.

The study was conducted in Kota Bharu, Kelantan, Malaysia involving three public higher learning institutions which are UiTM Kota Bharu, University Malaya, and Universiti Malaysia Kelantan. The respondents for this research are the staff of the three public higher learning institutions in Kota Bharu. The sample size selected is based on the population of the staff in these institutions according to the work of [6]. From the total number of staff obtain from the registrar of the three universities, the number of respondents chosen for this study are 150 respondents.

Three research objectives were identified in this research, which is listed as follows:

To identify the TQM (Total Quality Management) elements that are critical in delivering excellent service performance to students at public higher learning institutions.

To investigate the relationship between TQM (Total Quality Management) elements and excellent service performance to students at public higher learning institutions.

To identify the most dominant TQM (Total Quality Management) elements in achieving excellent service performance to students at public higher learning institutions.

\section{LITERATURE REVIEW}

In this section, the authors will discuss the variables that are selected by the researcher to conduct this research. This chapter will explain the elements which support all the variables selected namely management support, continuous improvement, training and education, and customer focus as the independent variables and service as the dependent variable.

\section{A. Service Performance}

Service performance is defined as how well the staff performs their job in providing services to achieve performance benefits. It is difficult to measure the service performance in service institutions compared to manufacturing. Service performance is important but is regarded as more complicated compared to the manufacturing context [7]. Performance excellence in higher education depends in part upon the effective management of PIs (Performance Indicators). PIs provide a mechanism for 
monitoring and analyzing performance [8]. There are several indicators to measure the service performance:

\section{B. Academic Performance}

Academic performance is a primary indicator to most universities in measuring performance. It is an icon that people use to indicate whether the university is good or bad [9]. The goals of a university affect the types of academic activities that should be included in the measurement. It also influences the type of management activities that should be done according to the production process in academic activities. Traditionally, academic activities include two components; research and education. In addition, graduation rate determines the number of students who completed their study or received a particular certificate or degree within the normal time frame. The higher the graduation rate, the higher academic performance.

\section{Faculty}

The goals of the faculty, department and individual level has become more specific and concrete to measure academic excellence. In higher education, the percentage of faculty with advanced certifications or degrees may be important for recognition as well as the reputation of the institutions. The training sessions per year will ensure the faculty members are in touch with the latest teaching methods or technologies. This will ensure that the students receive the best educational experience. Furthermore, the attendance rate from faculty and staff members are important since it may contribute to a negative effect on the institutions if they have a low attendance rate. In addition, the management does not have to retrain new employee regularly if the institutions have a high retention rate of the faculty and staff. High retention rate also helps students and professors to build better rapport [10].

\section{Facilities}

Facilities such as classrooms and computer labs will influence the delivery of learning to students. Up-to-date facilities and latest teaching material will create a comfortable environment and ensure that the students receive the best learning experience. Renovating older buildings effectively lowers the buildings' age. Thus, tracking the age of the buildings on campus helps to ensure that adequate maintenance is being provided to make sure that they are fully functional. Inspection is needed to make sure that facilities are in good condition [10].

\section{E. Technology}

The technology used will enhance the service performance of the university. The institutions need new technologies to meet the student expectations and demands. For example, multiple IT platforms for different services need to be implementing [11]. This new technologies will improve the administration and student support system. In this modern era, everything can be accessed easily through a better system raise from new technologies. For example, the students do not have to go to the administration department to register their courses. Everything can be accessed through the system either courses registration or class timetable and the institutions are able to update the information at any time. This system will give an advantage to both the institutions and students. With the internet, students are able to manage their academic system anytime and anywhere. As for the administrators, it is easier to manage the students through the system since the data can be saved in the system. New technologies are more systematic compare to the manual system. The institutions should know how to manage their system properly so that it can be access smoothly. In addition, blended learning such as online classes can be implemented. Social medias such as Facebook are convenient tools for information sharing with the students as they are active social media users.

\section{F. Transportation}

The availability of transportation options that have been provided to students by the institution might be a good way to encourage attendance (Reilly, 2016). There is no reason for students to skip classes if the public transportation is efficient. Appropriate bus route and affordable transportation cost will encourage the students to use the transportation provided to them. The schedule of the transit must be consistent with the class hours so that the students do not miss the bus or wait for the transportation for too long.

\section{G. Accommodation}

The quality of the accommodation options certainly affects where students choose to live. The administrators should ensure that there is enough room for students to stay on campus. Survey about the quality of the accommodation is important to ensure that students perceived their tuition and fees are being utilized appropriately and administrators are responding to their feedback accordingly [10].

A good service performance of higher learning institutions will increase the university ranking. This will promote the institution's reputation and able to attract customers to experience their service. The university that provides quality service to students will increase the students' satisfaction. This view is supported by [12] who proposed the implementing of quality management is long-term profitability earnings achieved through satisfying customers. Many researchers and quality consultants insist that the proper implementation of TQM principles positively influences company performance in many dimensions [13]. One of the dimensions is customer satisfaction [14] [15]. In additional, the aims of TQM are to achieve customer satisfaction, cost effectiveness and defect free [16]. If the service has a very low rate of defects (literally none or zero), the customers will be satisfied with the services. As such, the public higher learning institutions need to reduce the waste in their service activities to the minimal in order to improve their service performance.

Furthermore, a recent study indicated that different TQM elements significantly affect different performance outcomes [17). It means that the researcher have to identify the TQM factors according to their study context and environment. Studies by several researchers such as [18] and [19] have attempted to explore the relationship between quality and performance in service organizations while [20], [21] and [22] investigated the relationship for a combination of manufacturing and service firms. According to these studies, 
the researchers found that effective quality implementation leads to performance improvement.

\section{H. Internal Customer}

The students are generally assumed to be the primary internal customer since they are the product of the process. They are also the laborers of the learning process and the internal customer of the delivery of the course material [23].The internal customer is the customer who is directly connected to the organizations. For instance, students experience most of the service provided by the institution. Therefore, it is fair to consider the students as the primary internal customers. As the students are significant customers of higher learning institutions, they are considered the most important stakeholder compared to other stakeholders [24].

\section{TQM (Total Quality Management)}

A successful quality strategy starts with an organizational culture that foster quality followed by the deeper understanding of the principles of quality. Quality means the ability of a product or service to meet customers' needs. There are many definitions of quality from the TQM gurus. Juran defined quality as a fitness for use and focus on quality control, quality improvement, and quality planning. Crosby defined quality as zero defects and focus on doing job right at the first time. Deming identified 14 points for implementing quality improvement and enhance performance. Nowadays, quality is very important to survive in the market [25] Quality has been considered as one of the most important driver in the global competition [26].

In addition, good quality practices may lead to many other good service performances. The organization is able to win the customers' heart by providing the best quality that will satisfy their needs and wants. The organization also obtain a competitive advantage if they satisfied the customers. TQM has been identified as a competitive advantage for an organizations' success since the 1980s.[12]. The organization should engage their employee in the necessary activities to achieve quality. Quality can be achieved through different management tools and philosophy. TQM (Total Quality Management) is considered one of the most important strategies in gaining the quality of products or services.

TQM is defined as a management philosophy that focuses on continuous improvement in all organizations' functions and operations to provide services and products that meet the customers' requirements and needs through cheaper, safer, better, faster and easier processing with the involvement of all employees with their leadership [25][27]. As such, TQM plays an important role in improving performance and productivity. TQM is a source of competitive advantage and could be the key to improve performance. Customers will prefer to use the services from organizations that provide high-quality services. Some customers are willing to pay higher prices as long as they received services that will satisfy their needs and wants. For example, parents are willing to send their children to private academic institutions even though they have to pay higher fees.
TQM's critical success factors were identified and explained in many studies but differ according to their study context and environment. In this study, the factors of the TQM used by the researcher as the independent variables are top management support, continuous improvement, training and education, process management and customer focus.

\section{J. Management Support}

The commitment of management plays a major role toward enhancing the organizational performance [28]. The leadership, strategic planning and commitment of the top management is one of the most important drivers of success as supported by [29] and [30]. Thus, the top management commitment is one of the most critical factors for TQM implementation. Meanwhile, [31] suggested good leadership should be implement by unifying the objective, determining the strategic planning, motivation and change. The leadership involved integrity, bravery, mercy, humor, emotion and wisdom [4]. Reference [32] stated in more detail that top management provides direction, facilities, guidelines and feedback for employees to achieve organizational objectives in continuous improvement of the quality of products and services. Management should give the authority to the employees to manage quality problem. In addition, top management have to believe in TQM and be committed to it [12]. The management must be aware of their workforce and also give motivation to them to improve their performance. As stated in the findings in the previous study, TQM is a managerial approach and without the support from the organizational leaders, the implementation of TQM would not succeed [33] The finding is in line with other studies such as [34] and [35].

\section{K. Continuous Improvement}

TQM requires a never-ending process of continuous improvement that covers people, equipment, supplier, materials, and procedures. The goal of continuous improvement is perfection which is never achieved but always sought. Plan-Do-Check-Act shows in Figure 1 is a circular model developed by Walter Shewhart in 1920s, a pioneer in quality management. After World War II, Deming took this concept to Japan during his work. The Japanese use the word kaizen to describe this concept of ongoing process of improvement. In the U.S, TQM and zero defects are used to describe continuous improvement efforts. The operations manager is known as the key player in building a work culture that support continuous improvement.

The first continuous improvement activity is plan. The organization needs to identify the problems and make a strategic plan to solve the problems. For example, UiTM is facing a problem in increasing cost to invest in new facilities. As such, UiTM need to plan a budget to solve this problem. The second activity involves testing the plan. Referring to the previous example, UiTM have to refer to the budget planning before they make an investment on the facilities to avoid over spending. Check is the third activity of continuous improvement. The organization needs to analyze whether the plan is proceeding as expected. In this case, UiTM have to analyze if the budgeting plan is worth using to control their 
spending. The last activity is Act which refers to implementing the plan. In this case, UiTM should spend on the new facilities based on the budget planning, if the budget is enough, UiTM is able to buy the new facilities.

\section{Training and Education}

TQM provides a more focused approach for training activities that is directed at the organizational strategy of quality improvement whether in terms of customer services and others. The training is also directed at providing the necessary skills and knowledge for all level of management in order to contribute to ongoing quality improvement. TQM does not happen by itself, the employees and top management need to acquire the necessary skills to be able to implement a successful TQM system.

Training can be defined as an activity that will change people's behavior as well as to increase the skills of an employee for a particular job. Training refers to planned effort by an organization to facilitate employees' learning of jobrelated competencies such as knowledge, skills or behaviors that are critical for successful job performance [36]. The aim of training is to enable employees to master the knowledge, skills, and behaviors emphasized in training programmes and apply in their day-to-day activities [37]. An effective training and education will result in the improvement of the employees' performance, improved communication skills, better services and increased knowledge.

The training structure must be top-down and involved all levels of management from top-level management to lower level management. TQM will be successful if all employers including top management and other managers are thoroughly educated in all aspects of TQM. Top management should receive TQM training first so that they can enhance their skills and knowledge and be able to develop a good TQM training strategy and plan for the other workforce. Two out of Deming's 14 points are related to training. Point 6 is "Institute training" which means that too often, workers have learned their job from other workers who has never trained properly. The other point is Point 13, "Institute a vigorous program of education and training" where the training should involve both management and the workforce.

The training activities must be continuous to meet changes in technology, the environment, its structure and also the people who work there. In the beginning, the training must take place on a regular basis like monthly and later on at least on a semester basis. Last but not least, the trainer should act as consultants to manage the training programmes. Expert outside trainers should be contracted if internal expertise is not available. A better trained and more knowledgeable workforce is crucial to sustained quality improvement. Training is no longer just a nice-to-have, it is a must-have [38].

\section{Customer Focus}

In order to increase the service performance, the organization need to focus on their customer. Learn to listen to customers' voice in order to fulfill their needs, wants and expectations. Fulfilment of customers' needs and wants is crucial for any industry since it will help the organization to increase and maintain the market share in the competitive environment. The company's agility is needed in meeting the customers' needs and desires [39]. Therefore, the ultimate goal of TQM should be customer satisfaction. The factors like cost, delivery, flexibility and service will affect customer satisfaction. In this study, the customers are students of the institutions. The institutions need to provide services that will meet the students' satisfaction and expectations.

\section{RESEARCH METHODOLOGY}

. This section will review the type of investigation, the study setting and the time horizon in conducting this research. At the same time, this chapter will also briefly explain the sampling process and the method used in collecting data from respondents.

This study used correlation to determine the most important practice that contributes to good service performance. For example, is management support and service performance related? Or are management support, continuous improvement, training and education, and customer focus associated with service performance? If so, which variable contributes the most in achieving good service performance?

In addition, the correlational study is conducted with minimal interference because the researcher applied the normal flow of work during data collection. The study observed the current practices implemented by the institutions in the three public higher learning institution in Kota Bharu. Questionnaires were distributed to the internal customer of the institutions namely the staff.

\section{A. Questionnaire}

The questionnaires in this research were based on the journals from previous research. Initially, the researcher observed the operational practices of the public higher learning institutions. In this study, the researcher identified that management support, continuous improvement, training and education, and customer focus as the most common operational practices practiced by the institutions. After identifying these independent variables, the researcher used the previous research, journals, and articles to obtain the elements which will support each variable that will be tested. After identifying all the elements supporting the selected variables, the researcher then developed the questionnaires by using all the related elements. The questionnaire contains six sections; Section A for demographic with nine questions, Section B for testing management support with five questions, Section $C$ for continuous improvement with six questions, Section $\mathrm{D}$ for training and education with five questions, Section $E$ for customer focus with five question and Section $F$ for measuring the dependent variable which is service performance to students at public higher learning institutions with seven questions. The researcher used open-ended and close-ended questions in Section A and while Likert scale is used for the other sections.

\section{B. Population}

The population is the entire group of people that the researcher wants to investigate. The population for this 
research is the academic staff and non-academic staff of the three public higher learning institutions in Kota Bharu i.e. UiTM Kota Bharu, Universiti Malaya and Universiti Malaysia Kelantan. The element for this population is the staff from group A and B. In order to get the population for this study, the researcher obtained the information on the number of staff from the three institutions. After identifying the number of population for the respondents the researcher determined the sample size.

\section{Sampling Method}

Sampling is the process of selecting a sufficient number of elements from the population. In this research, the researcher uses the Krejcie and Morgan (1970) table to determine the sample size for this research as follow:

TABLE 1: RESPONDENTS SAMPLE SIZE

\begin{tabular}{|l|c|l|c|}
\hline $\begin{array}{l}\text { Public Higher Learning } \\
\text { Institutions }\end{array}$ & Population & $\begin{array}{l}\text { Sample } \\
\text { Size }\end{array}$ & $\begin{array}{l}\text { Quota } \\
\text { Sampling }\end{array}$ \\
\hline UiTM Kota Bharu & 34 & 32 & 24 \\
\hline Universiti Malaya & 20 & 19 & 14 \\
\hline $\begin{array}{l}\text { Universiti Malaysia } \\
\text { Kelantan }\end{array}$ & 241 & 148 & 112 \\
\hline \multicolumn{2}{|c|}{ TOTAL } & 199 & 150 \\
\hline
\end{tabular}

Figures in Table 1 highlighted the number of the sample size from the population of each institutions using the Krejcie and Morgan (1970) table. The population of the staff for UiTM Kota Bharu is 34, University Malaya is 20, and Universiti Malaysia Kelantan is 241, so the sample size for UiTM Kota Bharu is 32, University Malaya is 19, and Universiti Malaysia Kelantan is 148. The actual sample size for this study is 199 .

The researcher then used quota sampling to limit the number of the respondents to 150 respondents. The respondents were selected by the availability of the respondents at that particular time. Using this type of sampling, the researcher was able to save time, cost and effort to conduct this study. In conclusion, the questionnaires were distributed to 24 respondents from UiTM Kota Bharu, 14 respondents from University Malaya and 112 respondents from Universiti Malaysia Kelantan.

To ensure that all questionnaires were completed and collected within the time-frame, the researcher met with each respondent consists of academic and non-academic staff

\section{Conceptual Framework Independent Variables}

Total Quality Management (TQM) Elements:

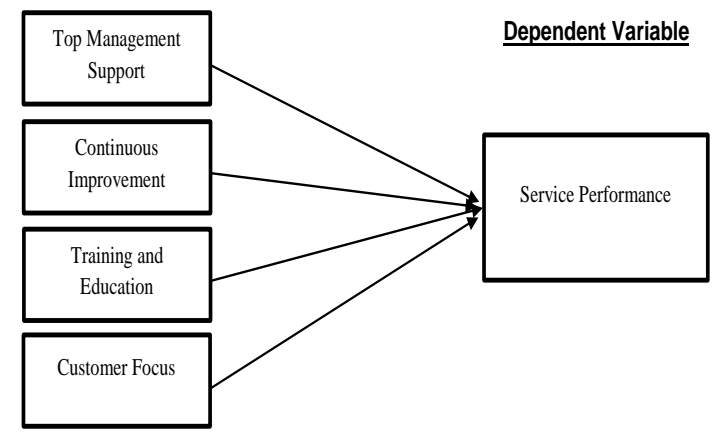

FIGURE 1: CONCEPTUAL FRAMEWORK

The theoretical framework in figure 1 suggests that the degree of change in service performance to students at public higher learning institutions depends on the management support, continuous improvement, training and education, and customer focus. Therefore, management support, continuous improvement, training and education and customer focus are the four independent variables influencing the service performance to students at public higher learning institutions as the dependent variable.

\section{DATA ANALYSIS}

This chapter will review the reliability and frequency analysis on the demographic factor of respondents. At the same time, the correlational analysis and multiple regression analysis will also be discussed and the result obtained will be interpreted. As for the multiple regression, the coefficient table and Anova table will also be interpreted.

In this section, the researcher will discuss the findings of the data and will explain further about the data obtained. The analysis of measurement and the findings are on the Total Quality Management (TQM) elements in achieving an excellent service performance to students at public higher learning institutions in Kota Bharu, Kelantan. It represents the result for the reliability test and frequency analysis on respondent profile, descriptive analysis on variables, correlation and multiple regression result. A sum of 150 questionnaires were distributed to the staff of three public institutions of higher learning in Kota Bharu which are UiTM Kota Bharu, Universiti Malaysia Kelantan and University Malaya. All of the questionnaires were fully completed and returned. The result of the survey was analyzed by using the Statistical Package for Social Sciences (SPSS) software.

Reliability Analysis (Cronbach's Alpha). The data collected was again subjected to the measure of reliability. 
TABLE 2: RELIABILITY ANALYSIS TABLE

\begin{tabular}{|l|l|r|c|}
\hline No & & $\begin{array}{l}\text { No of } \\
\text { Items }\end{array}$ & $\begin{array}{l}\text { Cronbach's } \\
\text { Alpha }\end{array}$ \\
\hline 1 & Management Support & 5 & 0.911 \\
\hline 2 & Continuous improvement & 6 & 0.910 \\
\hline 3 & Training and education & 5 & 0.866 \\
\hline 4 & Customer focus & 5 & 0.806 \\
\hline 5 & $\begin{array}{l}\text { Service performance to } \\
\text { students }\end{array}$ & 6 & 0.880 \\
\hline
\end{tabular}

The figures from the reliability analysis as shown in Table 2 revealed that all items have a high level of credibility based on the Cronbach's Alpha of greater than 0.600 .

\section{A. Correlation Analysis}

The correlation analysis was adopted to investigate the relationship between dependent variable which is service performance to students with the independent variables which are management support, continuous improvement, training and education, and customer focus. It was conducted by performing the Pearson Correlation Analysis. By performing Pearson correlation, the researchers are able to determine the magnitude, direction and the significant level of relationship between each variable.

The Pearson Correlation for management support is 0.226, which shows that management support has positive relationship with the service performance and these variables have a weak relationship because the value of Pearson Correlation in table 3 below indicates that the association is weak. Moreover, the significance value is 0.003 , and in conclusion, the management support is significantly correlated with service performance to students since its significant value is lower than 0.05 .

TABLE 3: PEARSON CORRELATION ANALYSIS

\begin{tabular}{|l|c|}
\hline & $\begin{array}{c}\text { Service } \\
\text { Performance }\end{array}$ \\
\hline Management support & $.226^{* *}$ \\
\hline Continuous improvement & $.465^{* *}$ \\
\hline Training and education & $.500^{* *}$ \\
\hline Customer focus & $.546^{* *}$ \\
\hline $\begin{array}{l}\text { **. Correlation is significant at the } 0.01 \text { level (1-tailed). } \\
\text { All correlation is significant at the } 0.01 \text { level (1 tailed) }\end{array}$ \\
\hline
\end{tabular}

The Pearson Correlation for continuous improvement is 0.465 , which shows that continuous improvement has a moderate relationship with service performance because the value of Pearson Correlation in table 3 indicates a moderate association. In conclusion, continuous improvement is correlated with service performance to students because its significant value is below 0.01 and it is significant. The Pearson Correlation for training and education is 0.500 , which indicated that training and education has positive relationship with the service performance and these variables have a moderate relationship. Therefore, the training and education is correlated with service performance to students because its significant value is below 0.01 and it is significant. The Pearson Correlation for customer focus is 0.546, which indicated that customer focus has positive relationship with the service performance and this variable have a moderate relationship because the value of Pearson Therefore, the customer focus is correlated with service performance to students because its significant value is below 0.01 and it is significant.

\section{B. Multiple Regression Analysis}

Using multiple regression analysis, the researchers identify the most important Total Quality Management (TQM) elements to achieve excellent service performance to students at public higher learning institutions in Kota Bharu, Kelantan. Malaysia.

The R-value is 0.699 and the $\mathrm{R}$ square is 0.488 as shown in Table 4 indicates that all independent variables have a moderate influence on the dependent variable. In other words, $48.8 \%$ changes in the dependent variable is derived from the independent variables which are management support, continuous improve, training and education, and customer focus while, the other $51.2 \%$ are from other variables which is unknown and need further investigation.

TABLE 4: MODEL SUMMARY

\begin{tabular}{|l|c|c|c|c|}
\hline Model & $\mathrm{R}$ & $\mathrm{R}$ Square & $\begin{array}{c}\text { Adjusted R } \\
\text { Square }\end{array}$ & $\begin{array}{c}\text { Std. Error of } \\
\text { the Estimate }\end{array}$ \\
\hline 1 & $.699^{\mathrm{a}}$ & .488 & .474 & .49481 \\
\hline a. & $\begin{array}{l}\text { Predictors: (Constant), Customer focus, Management support, } \\
\text { Training and education, Continuous improvement }\end{array}$ \\
\hline \multicolumn{4}{|l}{} \\
\hline
\end{tabular}

The significance level highlighted in the ANOVA table 5 below shows that the value is 0.000 which is below 0.05 which means the model is valid. Therefore, all the independent variables i.e. management support, continuous improvement, training and education, and customer focus does have an influence on the dependent variable i.e. service performance to students.

TABLE 5: ANOVA TABLE

\begin{tabular}{|l|l|l|l|l|c|c|}
\hline \multicolumn{2}{|c|}{ Model } & $\begin{array}{l}\text { Sum of } \\
\text { Squares }\end{array}$ & df & $\begin{array}{l}\text { Mean } \\
\text { Square }\end{array}$ & F & Sig. \\
\hline & Regression & 33.878 & 4 & 8.470 & 34.593 & $0.00^{\mathrm{b}}$ \\
\cline { 2 - 7 } & & 35.501 & 145 & .245 & & \\
\cline { 2 - 7 } & Residual & 69.379 & 149 & & & \\
\hline a. Dotal & Dependent Variable: Service performance to students \\
\hline b. & $\begin{array}{l}\text { Predictors: (Constant), Customer focus, Management support, Training } \\
\text { and education, Continuous improvement }\end{array}$ \\
\hline
\end{tabular}

Based on the figures shown in the coefficient table 6 below, the researchers are able to identify the most dominant TQM element that influence the service performance to students. In this study, customer focus is the most dominant TQM element to achieve excellent service performance to 
students because it has the highest Beta value which is 0.376 with 0.000 significant value. The researcher also found that management support $(p<0.972)$ does not provide enough evidence to influence the service performance to students because the significant value ( $p$-value) is above 0.05 . Customer focus is the most influential TQM practice with the highest Beta value of 0.376 and significant value of 0.000 .

\section{TABLE 6: COEFFICIENTS TABLE}

\begin{tabular}{|l|c|c|c|c|c|}
\hline \multicolumn{1}{|c|}{ Model } & \multicolumn{2}{|l|}{$\begin{array}{l}\text { Unstandardized } \\
\text { Coefficients }\end{array}$} & $\begin{array}{l}\text { Standardized } \\
\text { Coefficients }\end{array}$ & T & Sig. \\
\cline { 2 - 4 } & $\mathrm{B}$ & $\begin{array}{c}\text { Std. } \\
\text { Error }\end{array}$ & Beta & & \\
\hline Constant) & .262 & .497 & & .528 & .598 \\
\hline $\begin{array}{l}\text { Management } \\
\text { Support }\end{array}$ & -.002 & .060 & -.002 & -.035 & .972 \\
\hline $\begin{array}{l}\text { Continuous } \\
\text { Improvement }\end{array}$ & .274 & .065 & .281 & 4.229 & .000 \\
\hline $\begin{array}{l}\text { Training and } \\
\text { education }\end{array}$ & .299 & .063 & .306 & 4.768 & .000 \\
\hline $\begin{array}{l}\text { Customer } \\
\text { Focus }\end{array}$ & .399 & .068 & .376 & 5.895 & .000 \\
\hline
\end{tabular}

Furthermore, there is no multicollinearity because all of the tolerance value are above 0.2 which means that all respondents were able to understand the questions. All the questions were also not redundant. Besides, all of the VIF (Variance Inflation Factor) are below 10. Therefore, the result of the test shows that the questions are good and not redundant with other questions.

\section{CONCLUSION AND RECOMMENDATION}

It can be concluded from the results of the study that the most important element of TQM in achieving excellent service performance is customer focus. The three institutions need to give more focus to their customer i.e. the students of the institutions. The institutions also need to place high priority in giving the student the best service performance.

Management support have a weak relationship with the service performance maybe because all of the three institutions are only branch campuses. The environment and management of the branch campus is different from the main campus which maybe the cause of management support having a weak relationship with the service performance.

The other two elements i.e. training and education and continuous improvement have a moderate relationship with the service performance to students. This could indicate that these elements are important to achieve an excellent service performance.

Since customer focus is the most dominant TQM elements to achieve excellent service performance to students, the public higher learning institutions should give more focus on students' satisfaction since the students are the primary internal customer. The institutions need to provide services that will enable them to meet the customers' expectation and satisfaction.
As for the management support, the element has a weak relationship with service performance. The researcher recommends that the main campus of these three branch campuses determine the problem with the management support at branch campuses. Top management has to provide clear direction in order for the campuses to achieve organizational objectives in the continuous improvement of the quality of services because management support supposedly fall within the most important element in achieving an excellent service performance. Management support is like the driver of the service performance and will determine the strategy to improve the service performance to students.

The main campus should also provide well-equipped facilities, adequate transportation and comfortable accommodation to these branch campuses so that the branch can improve their service performance to students. Inadequate facilities will affect the service performance of these branch campuses.

Future researchers who are interested to conduct a study on the same topic should utilized management support as one of the variables in the research. In addition, the researchers would proposed to use other variables not included in this study to identify the significant variables that may influence service performance. The authors also recommend that future researcher to increase the sample size for similar study. There may be a possibility that the bigger sample size may resulted in better data analysis.

\section{Acknowledgment}

The authors would like to express our gratitude to the top management which include the rector office, the office of Academic Affairs and the office of Research, Industrial Linkages and Alumni. We would also like to thank all the staff and students of UiTM Terengganu who has given any assistance directly or indirectly in the completion of this article.

\section{REFERENCES}

[1] B. Dale. Managing Quality, Fifth Edition, John Wiley \& Sons, 2003.

[2] M.M. Ahmad and R. Elhunim. Critical quality factors for successful TQM implementation in Libyan oil and gas sector. Benchmarking: An International Journal, 2014, pp 713-733.

[3] S. H. Mehra. TQM as a management strategy for the next millennia. International Journal of Operations \& Production Management, 2001, pp 855-876.

[4] M. M. Altayeb and M. B. Alhasanat. Implementing total quality management (TQM) in the Palestinian construction industry. International Journal of Quality \& Reliability Management. 2014, pp 878-887.

[5] M. S. Bryant. Challenges facing higher education institutions. 17 October 2013, Retrieved from https://beyond2015.acu.ac.uk/submissions/view?id=106 
[6] R.V. Krajcie and D. W. Morgan. Determining sample size for research activities. Educational and psychology measurement. 1970. pp 607-610.

[7] K. B. Pawar. The PSO triangle: designing product, service and organization to create value. International Journal of Operation \& Production Management, 2009, pp 468-493.

[8] C. S. Muhammad Asif. A composite index for measuring performance in higher education institutions. International Journal of Quality \& Reliability Management. 2014, pp $983-1001$.

[9] X. Wang. Performance measurement in universities: managerial perspective. Paperwork University of Twente. 17 January 2010, pp. 2-88.

[10] M. Reilly. Key performance indicators for schools \& education management. 24 May 2016. Retrieved from Clear Point Strategy: https://www.clearpointstrategy.com/key-performanceindicators-in-education/

[11] J. Grove. 7 key challenges for UK higher education. 5 August 2015. Retrieved from the world university ranking https://www.timeshighereducation.com/features/7-keychallenges-uk-higher-education

[12] E. Boateng-Okrah and F.A. Fening. TQM implementation: a case of a mining company in Ghana. Benchmarking: An International Journal. 2012, pp 743759.

[13] J. C. Mensah. The status of total quality management (TQM) in Ghana. A comparison with selected quality awards winners from Turkey. International Journal of Quality \& Reliability Management, 2012, pp 857-871.

[14] H. Arasli. Towards business excellence in the hospitality industry: a case for 3-, 4-, and 5-star hotels in Iran. Total Quality Management \& Business Excellence, pp 573-590.

[15] J. Antony, J. What does the future hold for quality professionals in organisations of the twenty-first century? The TQM Journal, 2013, pp 677-685.

[16] H.V. Harrington. Applying TQM to the construction industry. The TQM Journal. 2012, pp 352-362.

[17] E. Sadikoglu. The effects of total quality management practices on performance and the reasons of and the barriers to TQM practices in Turkey. Advances in Decision Sciences. 2014, pp 1-17.

[18] G. K. Kanji. Total quality management in UK higher education institutions. Total Quality Management, 1999, pp 129-153.

[19] B.B Rao. TQM and business performance in the services sector: a Singapore study. International Journal of Operations \& Production Management. 2000, pp 12931312.

[20] T. Powell. Total quality management as competitive advantage: a review and empirical study. Strategic Management Journal. 1995, pp 15-37.
[21] K. B. Hendricks. Does implementing an effective TQM program actually improve operating performance? Empirical evidence from firms that have won quality awards. Management Science. 1997. Pp 1258-1274.

[22] G. Easton. The effects of total quality management on corporate performance: an empirical investigation. Journal of Business. 1998, pp 253-307.

[23] M. Sirvanci. Are students the true customers of higher education. Quality Progress. 1996, pp 378-412.

[24] N. Senthilkumar, SQM-HEI - determination of service quality measurement of higher education in India. Journal of Modelling in Management. 2011, pp 60 - 78.

[25] J. Motwani, "Critical factors and performance measures of TQM." The TQM magazine 13, no. 4 2001, pp 292-300.

[26] M. T. Demirbag. An analysis of the relationship between TQM implementation and organizational performance evidence from Turkish SMEs. Journal of Manufacturing Technology Management. 2006, pp 829-847.

[27] Kaur, M. S. (2012). An evaluation of the synergic implementation of TQM and TPM paradigms on business performance. International Journal of Productivity and Performance Management, pp 66-84.

[28] C. Valmohammadi. The impact of TQM implementation on the organizational performance of Iranian manufacturing SMEs. The TQM Journal. 2011, pp 496509.

[29] Beer, M. (2003). Why total quality management programs do not persist: the role of management quality and implications for leading a TQM transformation. Decision Sciences, 623-642.

[30] F. Vouzas, and A. Psychogios. Assessing managers' awareness of TQM. The TQM Magazine. 20017, pp 62-75

[31] A.K. Sabella. Quality management practices and their relationship to organizational performance. International Journal of Operations \& Production Management. 2014, pp 1487-1505.

[32] A.K Singh and Sushil. Modelling enablers of TQM to improve airline performance. International Journal of Productivity and Performance Management. 2013, pp 250275.

[33] J. A. Gholamhossein Mehralian. TOPSIS approach to prioritize critical success factors of TQM: Evidence from the. The TQM Journal. 2016, pp 235 - 249.

[34] J.F. Antony. Comparing total quality management success factors in UK manufacturing and service industries: some key findings from a survey. Journal of Advances in Management Research. 2004, pp 32-45.

[35] H. S. Khanna. Identifying and ranking critical success factors for implementation of total quality management in the Indian manufacturing industry using TOPSIS. Asian Journal on Quality. 2011, pp 124-138. 
[36] R. A. Noe, (2009). Employee Training and Development. Retrieved from fifth edition http://serverlib.moe.gov.ir/documents/10157/42675/Emplo yee+Training+and+Development.pdf

[37] J. P. Piyali Ghosh, J. P. Evaluating effectiveness of a training programme with trainee reaction. Industrial and Commercial Training. 2011. pp 247 - 255.
[38] B. Ferketish. HRD \& Quality: The Chicken or the Egg. Training and Development, 1992, pp 39-42.

[39] Rajabzadeh, A. M. (2013). Developing a model for agile supply: an empirical study from Iranian pharmaceutical supply chain. Iranian Journal of Pharmaceutical Research, 189-201. 